\section{Flurprimidol Substrate Drenches and Foliar Sprays Control Growth of 'Blue Champion' Exacum}

\author{
Brian E. Whipker, Ingram McCall, and Brian A. Krug
}

AdDITIONAL INDEX WORDS. Exacum affine, growth retardant, persian violet, Topflor

SumMARY. Flurprimidol was applied as a foliar spray $(12.5,25.0,37.5,50.0$, or $\left.62.5 \mathrm{mg} \cdot \mathrm{L}^{-1}\right)$ or as a substrate drench $(0.015,0.03,0.06,0.12$, or 0.24 $\mathrm{mg}$ /pot a.i.) to determine its efficacy on 'Blue Champion' exacum (Exacum affine). Flurprimidol substrate drenches were more consistent in controlling plant growth than foliar sprays. Substrate drenches of $0.03 \mathrm{mg} /$ pot a.i. or foliar sprays $\geq 50 \mathrm{mg} \cdot \mathrm{L}^{-1}$ resulted in smaller plant heights and diameters than the untreated control. With the use of flurprimidol, exacum growers have another plant growth regulator (PGR) available to control excessive growth.

$\mathrm{E}$ xacum is native to the Socotra Islands off the coast of the Saudi peninsula (Liberty Hyde Bailey Hortorium, 1976). It is grown primarily in the spring and summer months to economically permit warmer greenhouse production temperatures of up to $30 / 19^{\circ} \mathrm{C}$ day/night (Harbaugh and Waters, 1982; Larson, 1981; Sweet, 1982). With warmer growing temperatures, excessive growth can be a problem and height control measures may be required. Sweet (1982) recommended one to three daminozide (BNine; Chemtura, Middlebury, Conn.) foliar sprays at $2500 \mathrm{mg} \cdot \mathrm{L}^{-1}$, with the first application being applied 7 to 10 $\mathrm{d}$ after transplanting the plug.

Recommendations for paclobutrazol (Bonzi; Syngenta, Greensboro, N.C.) and flurprimidol vary. Hasek et al. (1986) recommended applying paclobutrazol as a $75 \mathrm{mg} \cdot \mathrm{L}^{-1}$ foliar spray or as a substrate drench at 0.25 to $0.75 \mathrm{mg}$ a.i. per 6 -inch-diameter pot. Barrett et al. (1986) recommended a foliar spray of $50 \mathrm{mg} \cdot \mathrm{L}^{-1}$ paclobutrazol or $25 \mathrm{mg} \cdot \mathrm{L}^{-1}$ flurprimidol for 'Blue Champion' exacum. Newman and Follett (1986) results contradicted the other reports because foliar sprays of

Department of Horticultural Science, Box 7609, North
Carolina State University, Raleigh, NC 27695-7609.

This research was funded in part by the North Carolina Agricultural Research Service (NCARS), Raleigh, NC 27695-7643. Use of trade names in this publication does not imply endorsement by the NCARS of products named or criticism of similar ones not mentioned. Thanks to Jeff Nameth of the Fred C. Gloeckner Co. for the plants; Fafard for the root substrate; Scotts for the fertilizer; Dillen Products for the pots; and for grant support, Rockwell Farms, the North Carolina Commercial Flower Growers' Assoc., and SePRO Chemical Co. paclobutrazol $\leq 480 \mathrm{mg} \cdot \mathrm{L}^{-1}$ and $\leq 15$ $\mathrm{mg} \cdot \mathrm{L}^{-1}$ flurprimidol were ineffective in controlling growth of 'Elfin' exacum.

Flurprimidol has been labeled as Cutless (SePRO Corp., Carmel, Ind.) for ornamental crop use in the U.S. and commercially introduced as Topflor for greenhouse crops in Europe. Previous research with exacum (Barrett et al.,1986; Newman and Follett, 1986) used a $1.5 \%$ flurprimidol formulation of Cutless that was labeled for turf. The formulation being introduced into the U.S. for greenhouse plants is a $0.38 \%$ concentrate and has not been evaluated on exacum as a foliar spray or as a substrate drench. Therefore, this study was conducted to determine recommended foliar spray and substrate drench concentrations for height control of 'Blue Champion' exacum.

\section{Materials and methods}

'Blue Champion' exacum seedlings [50 cell size (cell measured 5 $\mathrm{cm}$ deep $\times 4.5 \mathrm{~cm} \times 4.5 \mathrm{~cm})]$ were transplanted on 28 May into 6-inchdiameter round, plastic pots with a volume of $1.2 \mathrm{~L}$ and filled with Fafard 4P (Fafard Inc., Anderson, S.C.) substrate. Plants were fertilized at each irrigation with $150 \mathrm{mg} \cdot \mathrm{L}^{-1} \mathrm{~N}$ using $15 \mathrm{~N}-2.1 \mathrm{P}-12.5 \mathrm{~K}$ (Excel 15-5-15 Cal-Mag; The Scotts Co., Marysville, Ohio). Greenhouse day/night set point temperatures were $80 / 70{ }^{\circ} \mathrm{F}$. The plants were grown under natural day lengths.

The plant growth regulators were applied on 21 June. Foliar spray treatments consisting of flurprimidol $(0.38 \%)$ at $0,12.5,25.0,37.5,50.0$, or $62.5 \mathrm{mg} \cdot \mathrm{L}^{-1}$ were applied using a volume of $0.5 \mathrm{gal} / 100 \mathrm{ft}^{2}$. Substrate drench treatments of flurprimidol at 0 , $0.015,0.03,0.06,0.12$, or $0.24 \mathrm{mg} /$ pot a.i. were applied using $4 \mathrm{fl} \mathrm{oz}$ of solution per pot. These concentrations corresponded to $0.125,0.25,0.5 \mathrm{l}$, 1.01 , or $2.03 \mathrm{mg} \cdot \mathrm{L}^{-1}$, respectively. The experiment was a completely randomized design with eight single-plant replications. On 27 Aug., total plant height (measured from the pot rim to the uppermost part of the inflorescence), and plant diameter (measured at the widest dimension and turned $90^{\circ}$, and then averaged) were recorded.

Data for plant height and plant diameter were tested with analysis of variance by general linear model (SAS Institute, Cary, N.C.). Plant height and diameter values were regressed using the PROC REG procedure to determine the best-fit linear or quadratic model for the flurprimidol application method (foliar spray or substrate drench). Terms of the model were judged to be significant or nonsignificant and included in the final model based on a comparison of $F$ values at $\alpha=0.05$.

\section{Results and discussion}

Substrate DRENChes. The response of 'Blue Champion' plants was best fit to a quadratic model with the smallest plants averaging $14.2 \mathrm{~cm}$ tall when treated with $0.24 \mathrm{mg} /$ pot a.i. flurprimidol (Fig. 1). This concentration would be considered excessive by commercial growers (M. Bell, personal communication). The plants were $12 \%$ to $17 \%$ shorter when treated with 0.03

\begin{tabular}{llll}
\hline $\begin{array}{l}\text { Units } \\
\text { To convert U.S. to SI, } \\
\text { multiply by }\end{array}$ & U.S. unit & SI unit & $\begin{array}{l}\text { To convert SI to U.S., } \\
\text { multiply by }\end{array}$ \\
\hline 29.5735 & $\mathrm{fl} \mathrm{oz}$ & $\mathrm{mL}$ & 0.0338 \\
3.7854 & $\mathrm{gal}$ & $\mathrm{L}$ & 0.2642 \\
$4,074.5851$ & $\mathrm{gal} / 100 \mathrm{ft}^{2}$ & $\mathrm{~L} \cdot \mathrm{ha}^{-1}$ & 0.0002 \\
2.54 & inch $(\mathrm{es})$ & $\mathrm{cm}$ & 0.3937 \\
28,350 & $\mathrm{oz}$ & $\mathrm{mg}$ & $3.5274 \times 10^{-5}$ \\
1 & $\mathrm{ppm}$ & $\mathrm{mg} \cdot \mathrm{L}^{-1}$ & 1 \\
$\left({ }^{\circ} \mathrm{F}-32\right) \div 1.8$ & ${ }^{\circ} \mathrm{F}$ & ${ }^{\circ} \mathrm{C}$ & $\left(1.8 \times{ }^{\circ} \mathrm{C}\right)+32$
\end{tabular}


and $0.06 \mathrm{mg} /$ pot a.i. of flurprimidol, respectively, when compared to the untreated control plants.

'Blue Champion' plant diameter was also best fit to a quadratic model (Fig. 1). 'Blue Champion' plants treated with $0.03 \mathrm{mg} /$ pot a.i. were $11 \%$ smaller in diameter compared to the untreated control. Smaller-diameter plants would be advantageous to wholesale producers because a greater number of pots could fit on shipping carts and trucks.

The growth control achieved in this experiment with a $0.03 \mathrm{mg} / \mathrm{pot}$ a.i. flurprimidol drench was eight times less than the 0.25 to $0.75 \mathrm{mg} /$ pot a.i. paclobutrazol drench concentration recommended by Hasek et al. (1986). Flurprimidol and paclobutrazol substrate drench activity has varied with plant type. Substrate drenches of 2 $\mathrm{mg}$ /pot a.i. flurprimidol or paclobutrazol had similar efficacies on 'Pacino' pot sunflower (Helianthus annuus) (Whipker et al., 2004), but with pot tulips (Tulipa spp.) a $0.5 \mathrm{mg} /$ pot a.i. of flurprimidol provided similar control as $1 \mathrm{mg} /$ pot a.i. of paclobutrazol (Krug et al., 2005). The use of lower chemical concentrations would be an advantage of flurprimidol if it extends over a wide number of crops.

Foliar sPraYs. A linear relationship existed between increasing concentrations of flurprimidol foliar sprays and plant height for 'Blue Champion' exacum (Fig. 2). Plant height was $14 \%$ shorter than the untreated control when sprayed with $\geq 50 \mathrm{mg} \cdot \mathrm{L}^{-1}$ flurprimidol. Wide plantto-plant variations occurred for all spray concentrations and is reflected in the low $r^{2}$ values. For example, the coefficient of variation (CV) for sprays averaged $12 \%$ and $9.6 \%$, respectively, for plant height and diameter, whereas the $\mathrm{CV}$ for drenches averaged $6.4 \%$ and $5.7 \%$, respectively, for plant height and diameter.

'Blue Champion' plant diameter response to flurprimidol foliar sprays was also best fit to a linear model (Fig. 2 ). Plant diameter was $8 \%$ smaller than the untreated control plants when sprayed with $12.5 \mathrm{mg} \cdot \mathrm{L}^{-1}$ flurprimidol and $20 \%$ smaller in diameter with 50 $\mathrm{mg} \cdot \mathrm{L}^{-1}$. The amount of growth control provided with $50 \mathrm{mg} \cdot \mathrm{L}^{-1}$ flurprimidol was within the range acceptable to commercial greenhouses (M. Bell, personal communication). When applied as a foliar spray, the efficacy of $50 \mathrm{mg} \cdot \mathrm{L}^{-1}$

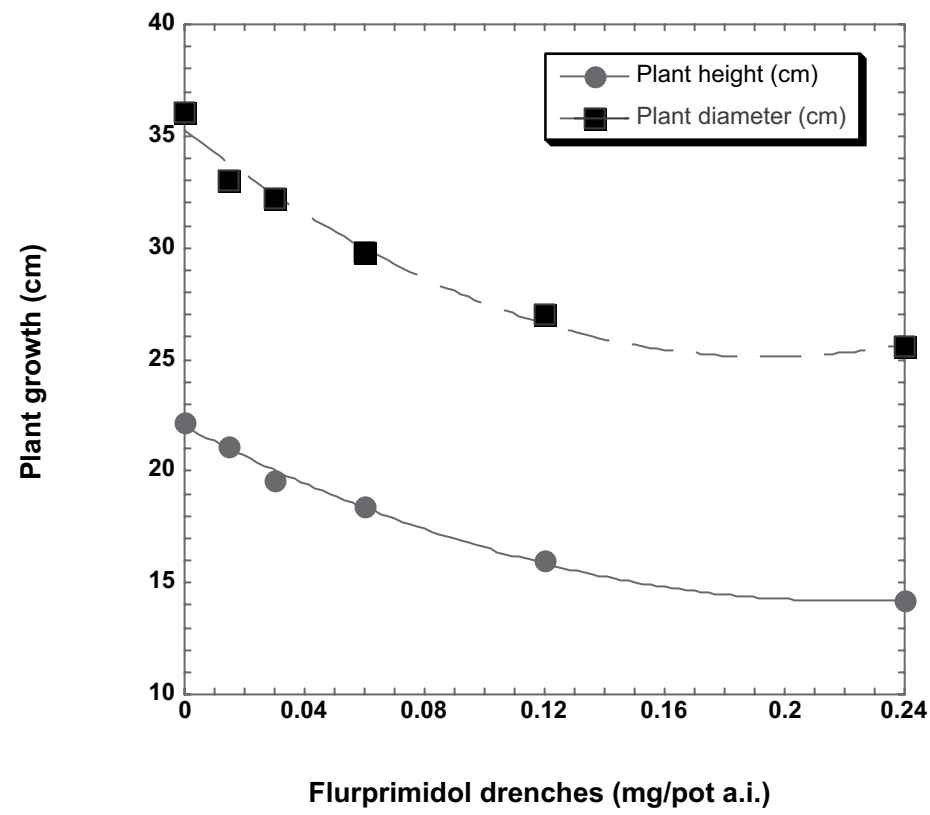

Fig. 1. Flurprimidol substrate drench effects 'Blue Champion' exacum height and diameter. Regression lines were generated from the best-fit model $(n=8)$. Regression equations were $\mathrm{y}=22.0-71.2 \mathrm{x}+161.1 \mathrm{x}^{2}$ for plant height $\left(r^{2}=\mathbf{0 . 8 5}\right)$ and $\mathrm{y}=35.3-104.0 \mathrm{x}+267.2 \mathrm{x}^{2}$ for plant diameter $\left(r^{2}=0.81\right) .(1 \mathrm{mg}=3.5274$ $\times 10^{-5} \mathrm{oz} ; 1 \mathrm{~cm}=0.3937$ inch)

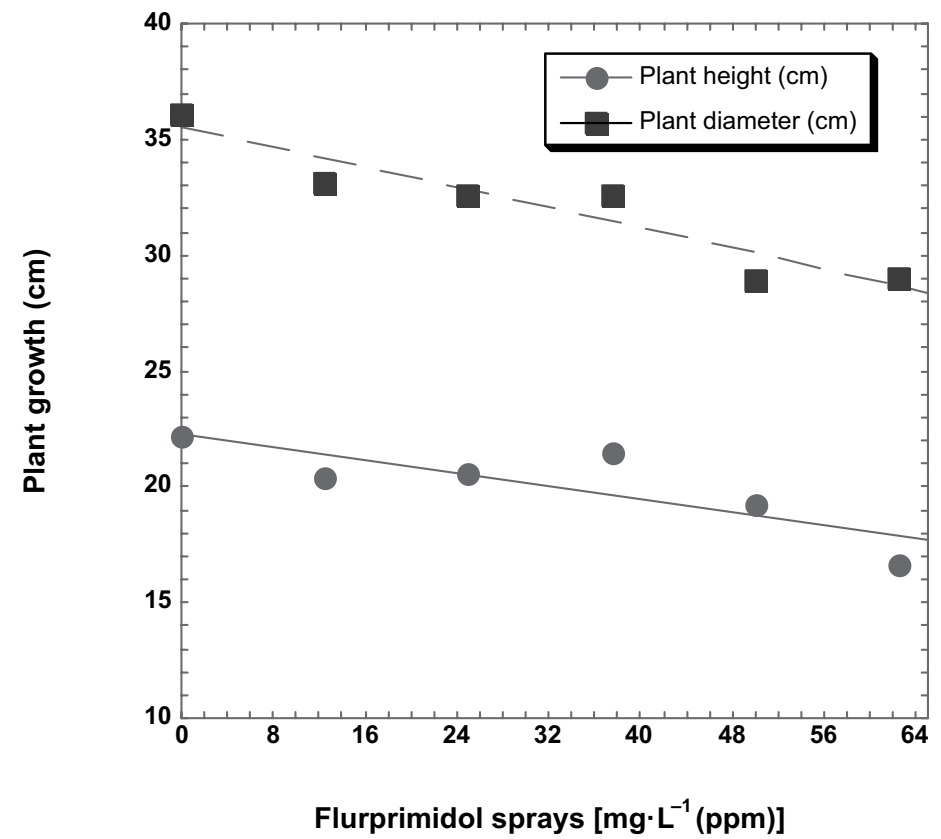

Fig. 2. Flurprimidol foliar spray effects 'Blue Champion' exacum height and diameter. Regression lines were generated from the best-fit model $(n=8)$. Regression equations were $\mathrm{y}=22.3-0.07 \mathrm{x}$ for plant height $\left(\gamma^{2}=0.29\right)$ and $\mathrm{y}=\mathbf{3 5 . 5}$ $-0.11 x$ for plant diameter $\left(v^{2}=0.38\right) .(1 \mathrm{~cm}=0.3937 \mathrm{inch})$

flurprimidol was similar to the optimal concentrations of 50 to $75 \mathrm{mg} \cdot \mathrm{L}^{-1}$ of paclobutrazol recommended by other researchers (Barrett et al., 1986; Hasek et al., 1986).

The optimal flurprimidol concentration recommended in our study is higher than the $25 \mathrm{mg} \cdot \mathrm{L}^{-1}$ recommended as a foliar spray to obtain $22 \%$ or more growth control of 'Blue Champion' exacum height when compared to the untreated control (Barrett et al., 1986). The difference in growth control may be due to the difference of 
flurprimidol formulation used. Barrett et al. (1986) used the $1.5 \%$ formulation of Cutless while this study utilized a $0.38 \%$ formulation. Previous research with exacum by Newman and Follett (1986) with the $1.5 \%$ turf formulation reported no height control with $\leq 15 \mathrm{mg} \cdot \mathrm{L}^{-1}$ flurprimidol or with $\leq 480$ $\mathrm{mg} \cdot \mathrm{L}^{-1}$ paclobutrazol. The cultivar Elfin used by Newman and Follett (1986) differed from our study ('Blue Champion') and they also did not report the age of the plants when the flurprimidol and paclobutrazol foliar sprays were applied, or how long after the application the plants were evaluated, which makes direct comparison difficult. Cultivar responses to PGRs vary and plants become less responsive to PGRs as they mature (Whipker et al., 2003) and may account for some of the differences in the control.

\section{Conclusions}

Flurprimidol substrate drenches were more consistent in controlling plant height and diameter of 'Blue Champion' exacum with less plant-toplant variation than flurprimidol foliar sprays. Substrate drenches of 0.03 $\mathrm{mg}$ / pot a.i. or foliar sprays $\geq 50 \mathrm{mg} \cdot \mathrm{L}^{-1}$ both resulted in significantly smaller plant heights and diameters than the untreated control. Flurprimidol substrate drenches may offer an economic advantage to producers because the amount of chemical required is up to eight times less than recommended for paclobutrazol. Producers should evaluate the trade-offs between the chemical and labor costs of applying a drench vs. a foliar spray to determine which application method best fits their production requirements.

\section{Literature cited}

Barrett, J.E., M.E. Peacock, and T.A. Nell. 1986. Height control of exacum and chrysanthemum with paclobutrazol, XE-1019, flurprimidol and RSW-0411. Proc. Fla. State Hort. Soc. 99:254-255.

Harbaugh, B.K. and W.E. Waters. 1982. Influence of controlled-release fertilizer on Exacum affine Balf. F. 'Elfin' during production and subsequent simulated home conditions. HortScience 17:605-606.

Hasek, R., R. Sciaroni, and G. Hickman. 1986. New growth regulator tested. Greenhouse Grower 4(2):52-53.

Krug, B.A., B.E. Whipker, I. McCall, and J.M. Dole. 2005. Comparison of flurprimidol to ancymidol, paclobutrazol, and uniconazole for tulip height control. HortTechnology 15(2):370-373.
Larson, R.A. 1981. Commercial production of exacum. North Carolina Commercial Flower Growers Bul. 25(4):1-5.

Liberty Hyde Bailey Hortorium. 1976. Hortus third: A concise dictionary of plants cultivated in the United States and Canada. Macmillan, New York.

Newman, S.E. and M. Follett. 1986. Effects of three chemical growth retardants on Exacum affine Balf. Miss. Agr. For. Expt. Sta. Res. Rpt. 11(21):1-4.

Sweet, J. 1982. Latest cultural techniques for gloxinias, exacum, streptocarpus, and begonias. Minn. State Florists Bul. 31(5):11-13.

Whipker, B.E., J.L. Gibson, T. J. Cavins, I. McCall, and P. Konjoian. 2003. Growth regulators, p. 85-112. In: D. Hamrick (ed.). Ball red book, 17th ed. Ball Publ., Batavia, Ill.

Whipker, B.E., I. McCall, J.L. Gibson, and T.J. Cavins. 2004. Flurprimidol foliar sprays and substrate drenches control growth of 'Pacino' pot sunflowers. HortTechnology $14: 411-414$. 